\title{
Bioelectrochemical system-mediated waste valorization
}

\author{
K. Chandrasekhar ${ }^{1} \cdot$ A. Naresh Kumar ${ }^{1} \cdot \operatorname{Tirath}_{\operatorname{Raj}^{1}} \cdot$ Gopalakrishnan Kumar $^{2}{ }^{2} \cdot$ Sang-Hyoun Kim ${ }^{1}$
}

Received: 23 March 2021 / Revised: 10 June 2021 / Accepted: 11 June 2021 / Published online: 9 July 2021

(c) The Author(s) 2021

\begin{abstract}
Bioelectrochemical systems (BESs) are a new and emerging technology in the field of fermentation technology. Electrical energy was provided externally to the microbial electrolysis cells (MECs) to generate hydrogen or value-added chemicals, including caustic, formic acid, acetic acid, and peroxide. Also, BES was designed to recover nutrients, metals or remove recalcitrant compounds. The variety of naturally existing microorganisms and enzymes act as a biocatalyst to induce potential differences amid the electrodes. BESs can be performed with non-catalyzed electrodes (both anode and cathode) under favorable circumstances, unlike conventional fuel cells. In recent years, value-added chemical producing microbial electrosynthesis (MES) technology has intensely broadened the prospect for BES. An additional strategy includes the introduction of innovative technologies that help with the manufacturing of alternative materials for electrode preparation, ion-exchange membranes, and pioneering designs. Because of this, BES is emerging as a promising technology. This article deliberates recent signs of progress in BESs so far, focusing on their diverse applications beyond electricity generation and resulting performance.
\end{abstract}

Keywords Microbial fuel cells $\cdot$ Waste valorization $\cdot$ Microbial electrolysis cell $\cdot$ Waste-to-energy $\cdot$ Biofuels

\section{Introduction}

Fossil fuel-based energy resources are the highest standard energy bases worldwide, which are accounted for $85.5 \%$. However, the fossil-fuel-based energy economy leads to environmental issues, such as greenhouse gas emissions, raising the atmospheric temperature, and causing severe health-related issues to human beings [1-4]. Further, there were limited reserves of fossil fuel; hence, there is a serious search for other alternative fuel sources [5, 6]. In this scenario, worldwide researchers are investigating environmentally friendly and renewable energy resources $[1,3,7]$. In recent times, for reasons, such as rapidly increasing global population, urbanization, industrialization, and unexpected climate change, water scarcity has increased [8]. Industries create a massive demand for water, and it is increasing day

Gopalakrishnan Kumar

gopalakrishnan.kumar@uis.no

1 School of Civil and Environmental Engineering, Yonsei University, 50 Yonsei-ro, Seoul 03722, Republic of Korea

2 Faculty of Science and Technology, Institute of Chemistry, Bioscience and Environmental Engineering, University of Stavanger, 4036 Stavanger, Norway to day due to rapid industrialization[7, 9]; hence, wastewater collection, treatment, and reuse are the best options for overcoming the problem mentioned above [10]. Wastewater resource recovery is not a novel approach; it was successfully applied in several European countries before establishing wastewater treatment facilities [11]. Several studies have successfully established physical, mechanical, biological, and hybrid physical and chemical treatment methods to valorize the waste water's high nutrient account [12]. The biological nutrient removal approach is cost-effective and versatile compared to other treatment methods [13]. Electrochemical energy processing has been under severe thought as alternate energy. This energy use will be considered to become more productive and much more environmentally safe. Anaerobic digestion was widely employed for biogas production from carbon-rich wastewater sources for over a century $[7,14]$. There are many inherent advantages of methane fermentation versus aerobic biological treatment, such as renewable energy production (methane), decreased energy prices by aeration removal, and lowered sludge processing and disposal prices [15]. As a result of interest in renewable energy production using hydrogen fuel cells, biological roots for hydrogen production from carbon-rich waste and wastewater have also attracted significant interest in recent years 
[16-18]. Sadly, existing fermentation methods can yield a total of only 2-3 $\mathrm{mol} \mathrm{H}_{2} / \mathrm{mol}$ glucose, considering a molar ratio capacity of $12 \mathrm{~mol} \mathrm{H}_{2} / \mathrm{mol}$ glucose, while most organic matter stays as volatile fatty acids and alcohols [19]. Therefore, the method is constrained to feedstocks with appropriate fermentation substrates, such that many are carbon-rich and highly biodegradable [5]. Although some bacteria's ability to engender electric current was first described over 100 years ago, this phenomenon did not begin to attract serious attention from scientists and engineers until the beginning of the present century $[11,20,21]$. The progress made over the last decade in the areas of bio-electrochemistry and BES has significantly led to the shift from the bench scale (laboratory) to the pilot-scale studies [22]. So, commercial expansion gives the impression to be getting closer [20].

Preliminary investigative efforts centered on exploring opportunities presented by BES for the treatment and valuation of different waste streams by electricity [23, 24]. So far, the spectrum of uses has increased significantly, spreading to various areas, for instance, bio-electro remediation, desalination of xenobiotic substances, biodegradation of polluted soil and wastewater, nutrient retrieval, metal recovery, or the bio-electro-synthesis of essential and value-added products, amid a lot of others applications [25, 26]. Further, BES has the flexibility together with a multi-layered design which paves the way for multiple uses than traditional fermentation industrial routes. Indeed, when BES is operated with the aim of biofuels and value-added chemical production, the external power supply is required to cross the thermodynamic barrier, and the provided electrical energy will be transformed into chemical energy and stored in the form of value-added products, such as acetic acid, Formic acid, hydrogen, and methane, etc. (Fig. 1) [27, 28].

Nowadays, researchers are seriously investigating the viable roots to produce value-added chemicals from BES using cheap and abundantly available carbon sources, such as carbon-rich wastewater (Food waste, agriculture waste, dairy waste, etc.) and carbon dioxide. Here, carbon-rich wastewater can directly be used for this prose or might be exposed to various pretreatment methods to convert complex waste into simple sugars and volatile fatty acids (VFAs) [29]. These simple sugars and VFAs can be used as potential feedstock for the bioelectrochemical synthesis of valueadded chemicals in BES. Bioelectrochemical synthesis technology is a process that uses the electrochemical interaction of electrochemically active microorganisms and electrodes [30, 31]. There are several reports available for more than 100 years stating that microorganisms can form electrical connections to devices. Further, microbial electrochemistry has been evolved as a discipline due to extreme interest in the opportunity of using BES for biofuel and alternate energy generation and waste remediation. BES has the capabilities to contribute to a circular economy, where carbon is cycled back into chemicals or electrical energy from renewable sources [20, 31, 32].

The main aim of this review article is to introduce and discuss a few significant and fascinating applications of BES for valuing waste streams for energy. It starts with a brief overview of BES operating concepts and its potential application as a viable treatment device and bioelectricity
Fig. 1 Possible application of bioelectrochemical systems in the direction of waste valorization

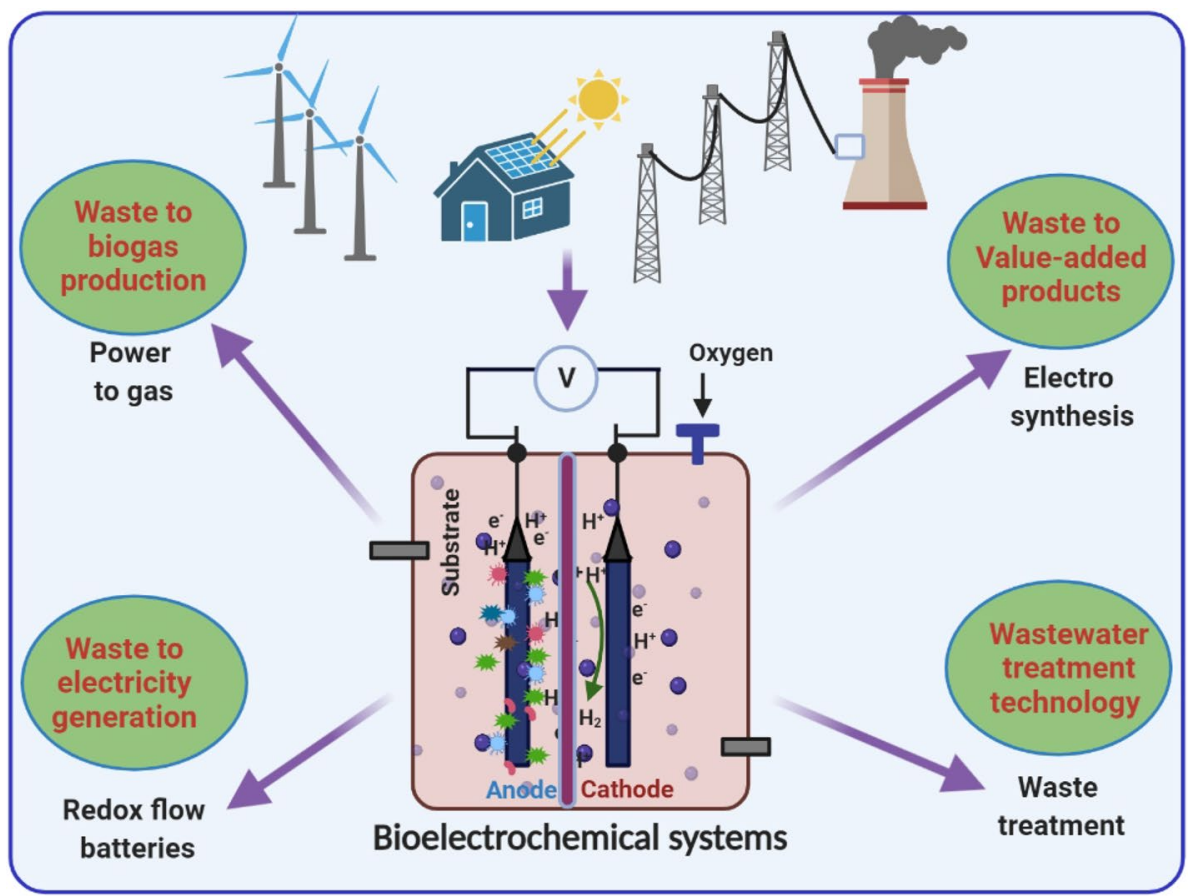


generation in wastewater energy valorization. In this direction, the present manuscript majorly focused on microbial fuel cells (MFC) and microbial electrolysis cells (MEC) and their role in waste valorization. BES will also be able to facilitate considerable energy savings for the processing industries of fertilizers, where it can recover nutrients from wastewater.

\section{Bioelectrochemical systems}

BES can be considered as a hybrid electrochemical device, whereas a minimum of one of the electrode reactions (anodic and/or cathodic) is carried out by microorganism/biocatalyst, generally under strictly anaerobic conditions $[17,33$, 34]. They provide the main feature of being functionally reversible with conventional electrochemical systems, i.e. BES can be controlled as galvanic cells or as electrolytic cells. The first galvanically powered BES systems were known as MFC and were typically called to this as MEC when they were operated under electrolytic mode by applying a small amount of external energy [35]. The actual cell voltage is smaller than the open-circuit voltage whenever the external circuit is closed, and the MFC is associated with the externally applied resistance. The cell voltage reduces when the energy portion of the electrochemical cell is discharged through resistive components, that is, the internal resistance [36]. While the growing number of BES archetypes and designs, some of which have arisen over the last decade, has redefined such language, it remains useful as it represents the two fundamental functionalities in BES. A

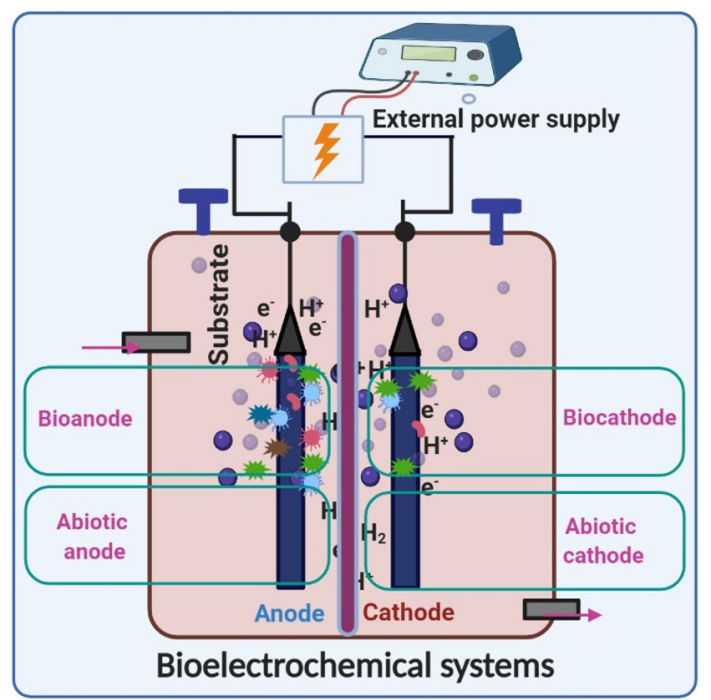

Fig. 2 Schematic representation of the principle of operation of bioelectrochemical systems graphical view of the theory of action of BES systems is shown in Fig. 2.

Compared to conventional fuel cells and enzymatic fuel cells, BES has many benefits under specific parameters. A wide variety of organic or inorganic matter, such as organic waste (agriculture waste, food waste, industrial waste, dairy waste, forest biomass, domestic waste, vegetable waste, etc.) and soil sediments, can be used as a source of fuel generation with the help of electrochemically active microorganisms [37]. It has been shown that MFCs are the most researched BESs while expanding the application of MFCs to diverse BESs has also received an extensive amount of research [38, 39]. The bioelectrochemical techniques have the ability to gather energy and produce value-added compounds from wastewater treatment. When we refer to the BES systems, it is very much dependent on the type of cathodic processes involved, such as MECs, microbial desalination cells, microbial electrosynthesis cells (MESs), and microbial metal recovery cells [40].

\section{Energy metabolism in bioelectrochemical systems}

Bacteria can obtain energy for the following reasons in BES. First, the primary direction of energy production is the indigenous respiration chain. In the BES system, generally, solid electrode materials/metals serve as electron acceptors for electrochemically active microorganisms and engage in the nature of the extracellular electron transport chain [41]. Further, electrochemically active microorganisms (Pseudomonas Sp. etc.) will also produce extracellular molecules which serve as electron mediators. Geobacter and Shewanella will continually obtain energy by decaying carbon-rich organic matter/organic acids for cell growth and metabolism when injected into the MFC system. Moreover, the redox balance has been preserved by releasing electrons into the anode that substitutes for the last accepter of insoluble metals [42]. The second alternative is also the transport of electrons. The possible process of synthesis of adenosine triphosphate (ATP) is that the emitted proton promotes proton motive force (PMF) production and drives ATP synthesis since electrons are being moved from cathodes into intracellular environments together with proton cotransport phenomena [43]. The energy provided by oxidative phosphorylation relative to aerobic breathing is not adequate for high cell proliferation during anaerobic environments. Due to the availability of reduced intracellular ATP, the key explanation is that levels of oxygen did not accompany the intermediary metabolites as electron acceptors [44]. Due to the direct or single-step transformation of substrate energy to electrical energy, maximum conversion efficacy can be attained with such equipment [45]. MFC can 
avoid unnecessary gas processing function and no specific energy input is needed for single-compartment MFC; furthermore, it can also be beneficial for broader use in areas without electric power facilities [21, 46].

A scientometric search is utilizing data accessible in the ISI Web of Knowledge (from 2001) indicating that the total amount of items available on bioelectrochemical systems accounts for 2335 records with a significant amount of citations $(59,734)$, typical citations for each item (25.58), and $\mathrm{H}$-index (101). According to the ISI Web of Knowledge records, literature related to the BES study showed a sharp rise after 2007, touched higher records of 358 in 2018 (total citations: 9878), followed by 2019 (higher records of 339 and overall citations of 12,577) with marginal variations.

Further, from the ISI Web of Knowledge, an average citation per year (from 2001 to 2020) also exposed a growing trend year by year, obviously signifying that quick and encouraging research is underway to make the BES method technologically viable. Available reports in ISI Web of Knowledge indicating that the research related to BES is rapidly increasing year to year. This research might be related to different applications of BES like bioelectricity generation, chemical synthesis, and waste remediation. In recent years, researchers were also focusing on developing a viable technology to utilize atmospheric carbon dioxide for value-added chemical synthesis, such as acetate, ethanol, etc. Few researchers are also aiming to produce bioplastic in the cathodic compartment of BES by providing appropriate conditions to support the growth of bioplastic-producing bacteria. In this case, using VFAs produce from the substrate oxidation in the anodic compartment as a feedstock for bioplastic production in the cathodic compartment might be an economically more viable process [47-49].

BESs and, among these, MFCs reflect a technology principle that enables sustainable biotechnology to utilize the energy stored in low-value biomass (for example, wastewater). The past of MFCs (the prototype BES) is marked by divergence, considering its attractive concept. The experimentation was revived in the 1960s in the NASA space program's context as emerging expertise for wastewater recycling in airships, relying on its first articles by Potter (1910) and Cohen (1931), which discovered hardly constrained significance. Nevertheless, developments in the area of photovoltaic (PV) systems have led to something like a declining concern in MFCs [50]. In recent times, the emerging understanding of both the challenges ahead connected to overwhelming reserves of fossil energy and also the increasing effects of environmental issues such as the greenhouse gasses contributed to both an increased understanding of the need to build methods for sustainable managing of the global ecosystem and an earth's assets [5, 51, 52]. Studies on microbial BESs, in particular MFCs, were revived in this course. In particular, the integration of BES into waste

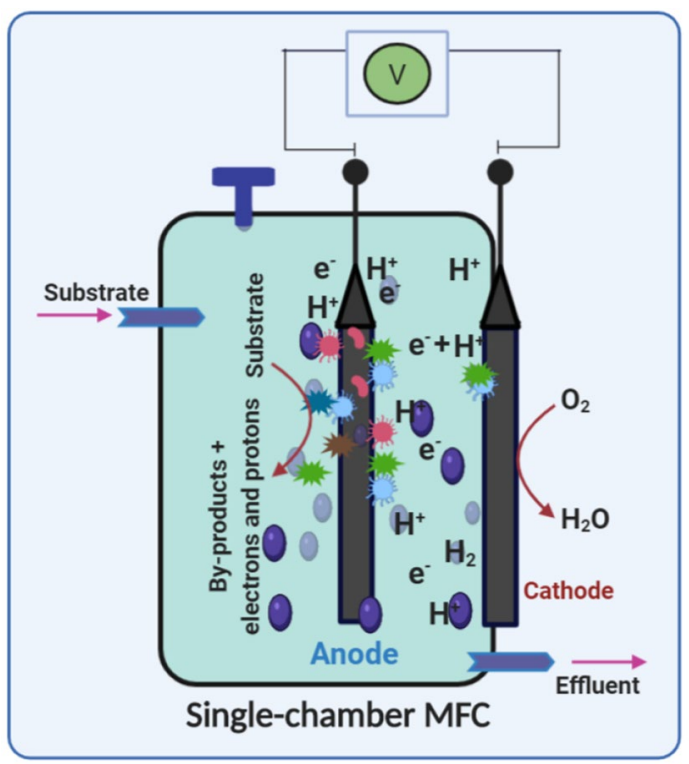

Fig. 3 Schematic representation of a single-chambered microbial fuel cell

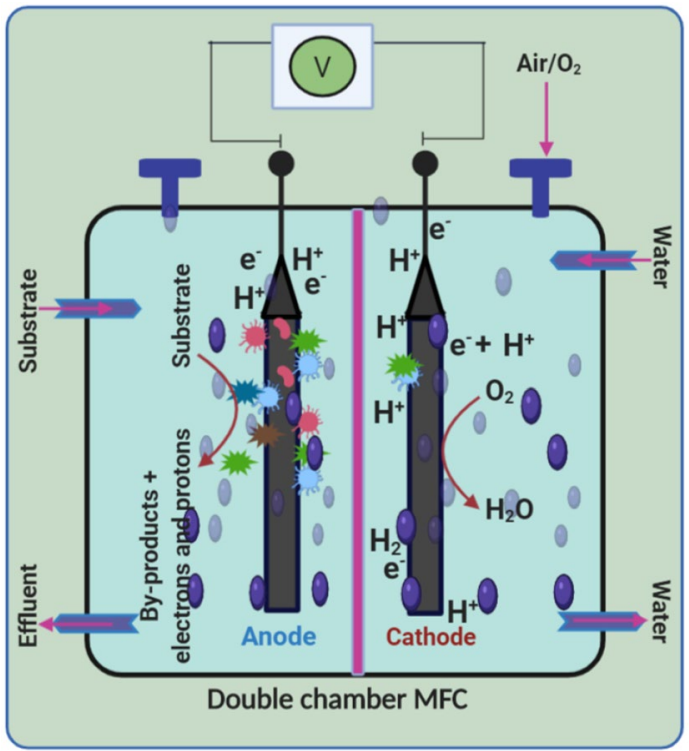

Fig. 4 Schematic representation of double-chambered microbial fuel cell

remediation for concurrent bioelectricity (bioenergy) generation and energy recovery is an excellent feature [53-55]. BESs comprise both an anode (where the mechanisms of biological substrate oxidation occur), and a cathode (where the electrons get reduced with oxygen). Both electrodes (anode and cathode) are connected to form a closed circuit through an external circuit [56]. The metabolic reactions near the anode/in the anode compartment are such as oxidation of a wide range of substrates, such as synthetic substrate 
(glucose, acetate, etc.) and carbon-rich organic waste (such as food waste, domestic waste, etc.). The redox reactions at the cathode of MFC may shift towards the reduction reaction-mediated chemical synthesis, like hydrogen or hydrogen peroxide. Besides this chemical synthesis, BES can also be applied to biosensors applications and biosynthesis of nanoparticles. BES contains electrochemically active microbes in the anode compartment, cathode compartment, or both electrodes. Single-chamber BES, do not contain separators (also popular as open-air cathode MFC) (Fig. 3). Whereas in the case of two-chamber systems (also popular as double chamber MFC) (Fig. 4), they contain a separator that separates the microorganisms or chemicals within only one of the two chambers.

This separator is made with cloth, selective membranes, ion-exchange membranes, etc. Whereas in the case of ionselective membranes, these allow only specific types of ions (anions or cations). The electrode materials will be prepared using different materials, including iron, copper, graphite, etc. Further, these electrodes will be given a coating with a catalyst to enhance the catalytic property. For example, BES operated with a graphite electrode (cathode) will be coated with a platinum catalyst to enhance the cathode compartment's oxygen redox reactions.

\section{Bioelectrochemical systems for wastewater valorization}

\section{BES for wastewater treatment and power production}

Early-stage BES research focused primarily on knowing how functional factors (such as electrode material, biocatalyst, $\mathrm{pH}$, temperature, etc.) influence their efficiency and develop new system designs and novel techniques to improve their overall process efficiency [21, 27, 57, 58]. Most of these investigations were conducted as electrolytes with synthetic media to allow investigators to maintain control over the substrate's composition [21]. Industrial effluents typically carry an immense amount of organic and inorganic pollutants, with organic compounds not just occurring at high concentrations and exhibiting an extensive range of organic molecules [54, 55, 59]. Several researchers carried out their research throughout the world to increase the power density level of BES and make the entire process economically viable to bring it to a large scale. Subsequent laboratory experiments with carbon-rich real wastewater were used to gain awareness of the ability of BES in the real world (Table. 1). These experiments have helped to measure the degree to which a natural substrate's existence influences reactors' efficiency. For example, BES operated with real field wastewater produced power densities in the range of several tens of $\mathrm{mW} / \mathrm{m}^{2}$, which contrasts with the hundreds and even thousands of $\mathrm{mW} / \mathrm{m}^{2}$ that can be achieved with synthetic effluents [60, 61]. Regardless of modern developments in electrode materials [27] and device configurations, BES power generation has not been dramatically enhanced. Problems, for instance, low conductivity and low power of the buffer, are often cited as the key aspects explaining the low output detected [21]. The MEC would certainly face similar obstacles, although economic viability conditions seem to be less stringent $[62,63]$. Besides, the disparity in architecture among the MFC and the MEC presents additional scaling problems. Aeration to the cathode invites complicated problems with a pilot-scale BES, as either the cathode chamber essentially be exposed to the atmospheric air or there is an additional aeration cost. Nonetheless, with a MEC, the cathode is anaerobic, simplifying the construction of a more massive structure, all of which outlines a more desirable MEC scenario.

Due to their low energy requirement, BESs are attracting interest because of their capacity to recover nutrients by means of ion migration across membranes. This project examines the potential for the use of nutrient bio-electroconcentration, an ionic nutrient form that is typically harvested from domestic wastewater and then concentrated and processed in centralized wastewater treatment plants, by further exploring the economic viability of the process [64].

Bacteria known as "electroactive bacteria" (electrogenic bacteria) were added to the anode, which is capable of oxidizing soluble organic substrates and generating electrons. These electrons are subsequently utilized in the reduction of water at the cathode, and that leads to an elevation in $\mathrm{pH}$ that
Table 1 Energy recovery from numerous wastewater as potential substrates in MFCs

\begin{tabular}{lllll}
\hline Substrate type & Reactor type & Bioelectricity & COD removal & References \\
\hline Brewery industrial wastewater & Double chamber MFC & $0.35 \mathrm{~W} / \mathrm{m}^{3}$ & $79-83 \%$ & {$[66]$} \\
Agro-food industry wastewater & Double chamber MFC & $27 \mathrm{~W} / \mathrm{m}^{3}$ & $83 \pm 11 \%$ & {$[67]$} \\
Vegetable oil industrial wastewater & Double chamber MFC & $2166 \mathrm{~mW} / \mathrm{m}^{2}$ & $80-90 \%$ & {$[68]$} \\
Seafood wastewater & Air cathode MFC & $570 \mathrm{~mW} / \mathrm{m}^{2}$ & $58 \pm 1.2 \%$ & {$[69]$} \\
Landfill leachate & Single-chamber MFC & $344 \mathrm{~mW} / \mathrm{m}^{3}$ & $90 \%$ & {$[70]$} \\
Silver laden artificial wastewater & Double chamber MFC & $3006 \mathrm{~mW} / \mathrm{m}^{3}$ & $82.7 \%$ & {$[71]$} \\
Fish market wastewater & Air cathode MFC & $420 \mathrm{~mW} / \mathrm{m}^{2}$ & $90 \%$ & {$[72]$} \\
\hline
\end{tabular}


Fig. 5 Bioelectrochemical systems mediated recalcitrant removal during anodic (substrate/wastewater oxidation) reactions and cathodic (substrate/pollutants reduction) reactions

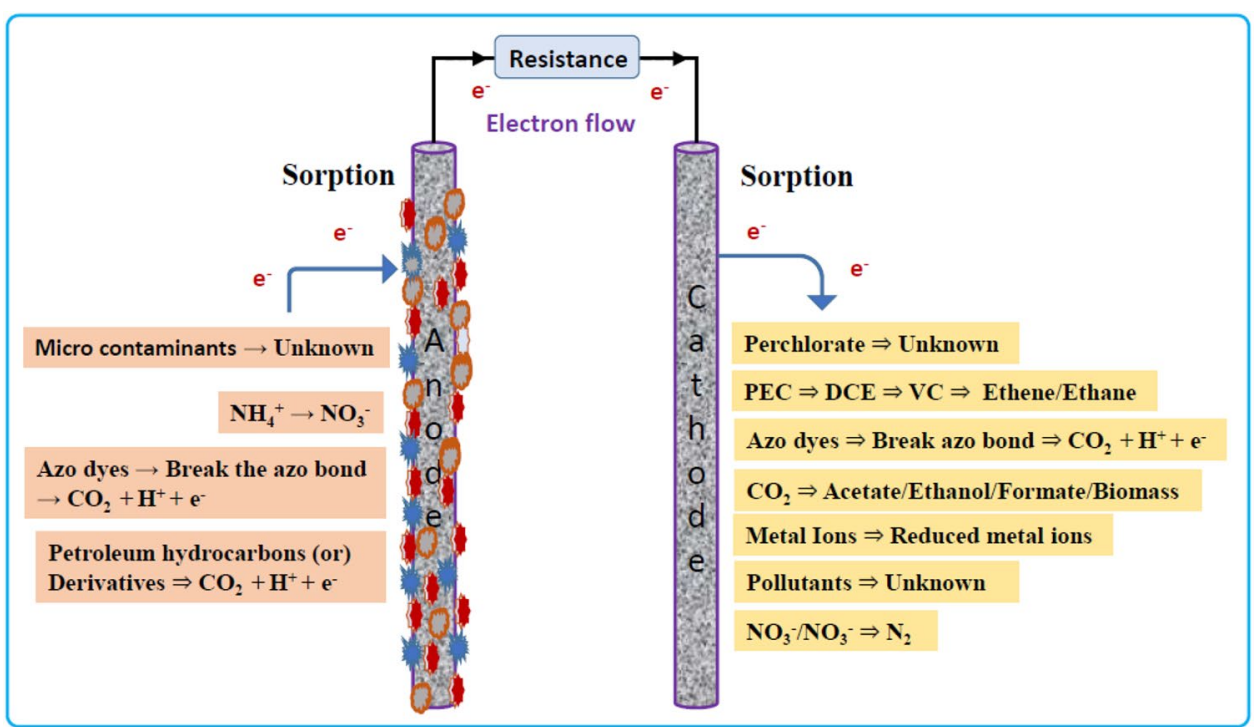

is quite near to the cathode (Fig. 5). As a result, phosphate may be eliminated by releasing calcium ions into the aqueous solution next to the cathode, resulting in the removal of calcium phosphate on the cathode's surface [65].

\section{BES for biohydrogen and biomethane production}

In recent years, BES is widely using as a potential biohydrogen producing system from a wide range of substrates, including wastewater [73, 74]. BES can produce biofuels, such as hydrogen and methane, by providing external electrical energy, as discussed in the above sections. For this purpose, MEC needed a very low electrical supply under optimum conditions [75, 76]. The rise in MEC should be due to the ongoing development of energy and resource recovery from zero value wastewater, particularly concerning the research related to hydrogen production from the dark-fermentation process and bioelectricity generation from MFCs [77, 78]. MEC offers a "one stone two birds" solution for energy generation (in the form of hydrogen/ methane) and waste remediation at the same time [79, 80]. MEC is an efficient approach for biohydrogen production; it can also utilize wastewater to produce hydrogen, methane, or other chemical compounds [77]. In MECs, electrochemically active microbes utilize carbon-rich organic substances near the anode and need significantly low energy compared to the electrolysis process [81]. Hence, these MECs can be directly used in the existing wastewater treatment plants with few sustainable energy modifications with concurrent waste treatment. This approach will make the waste treatment process economically viable process [77].

The process must occur for this to happen, and it will only happen if you provide at least $-0.414 \mathrm{~V}$ of voltage to the cathode. Compared to the usual fermentation biomethane synthesis, MEC technology takes far less energy input. It drives virtually all stoichiometric conversation of the feedstock to hydrogen. In contrast, dark fermentation has only been able to produce $33 \%$ of this potential. The efficiency of electrohydrogenesis depends on a number of factors, including the kind of electrodes used, the potential range, the kind of microorganisms, the design of the MEC reactors, and notably influenced by the feedstock type [82-84]. A hydrogen production and energy efficiency as high as possible was obtained using readily biodegradable substrates. Hydrogen synthesis in MECs using acetate as an electron donor is proven in Eqs. (1), (2) when temperature, $\mathrm{pH}$, and pressure are $25^{\circ} \mathrm{C}, 7.0$, and $1 \mathrm{~atm}$, respectively [85].

Anode $: \mathrm{CH}_{3} \mathrm{COOH}+2 \mathrm{H}_{2} \mathrm{O} \rightarrow 2 \mathrm{CO}_{2}+8 \mathrm{e}^{-}+8 \mathrm{H}^{+}$

Cathode $: 8 \mathrm{H}^{+}+8 \mathrm{e}^{-} \rightarrow 4 \mathrm{H}_{2}$

To enable biohydrogen promotion, the process known as electrohydrogenesis has been shown to have the capability of eliminating the endothermic barrier. Also, in this process, the small external energy as well as that produced by aturally occurring anode respiring bacteria work together to assist in the transfer of the electrons created through the respiration of the anode to the cathode, where they combine with protons and subsequently generate additional biohydrogen gas.

\section{BES for carbon dioxide valorization}

Raise in atmospheric carbon dioxide concentration is commonly considered one of the primary causes of global climate change [86]. Capturing carbon dioxide at significant sources of emissions and eventual sequester has been 
suggested as an effective method to reduce the deposition of carbon dioxide in the atmosphere, although this solution is of considerable public concern [87-89]. Some other options that are more appealing to public sentiment and might help alleviate the expense of reducing carbon dioxide emissions into the environment are the use of this gas as a raw material for manufacturing applications $[88,90]$. One of several options, in this case, is the transformation of carbon dioxide into chemical precursors or products [87, 91, 92].

The use of carbon dioxide as a green carbon feedstock for chemicals benefits this low-cost and plentiful carbon fuel. It successfully mitigates carbon pollution with immense environmental and social benefits [93]. To use carbon dioxide as feedstock, the condensed or atmospheric carbon dioxide source must first be collected and solubilized, whether by biotic or abiotic processes, for subsequent reduction reactions. Microbial electrosynthesis is a modern combination of biochemical and electro-chemical approaches to microbial cells for the transformation of dissolved carbon dioxide, especially multi-carbon precursor compounds, into valueadded organic compounds [94]. The specific benefit of BES for the recovery of carbon dioxide, while the availability of these electron sources can be sporadic, is that electrons are used to reduce electricity from coal, biogas or solar and wind sources. Because microbes can reap solar power at a pace 100 times higher than chemical output dependent on biomass, BES can help tackle the pressing problems of storage and delivery of renewable energies [95]. In BES, methanogens and acetogens were used as pure cultures or have been enriched in mixed cultures among certain autotrophic microorganisms. We outlined and evaluated quantitatively in this segment how MES was used for carbon dioxide use, which goods were produced, and the system's performance under different conditions. Furthermore, the BES's economic and environmental effects were examined and addressed for the recovery of carbon dioxide. BES for organic waste or carbon dioxide recovery is a possible method that enables harvesting electrons from solar energy, wind energy, biomass [94]. Excellent reports have been made on the working concepts and mechanisms for microbial electron transfer, rational evidence and structures, the economic viability of BES, and the BES principles and industrial capacity. The critical problem here is that carbon dioxide is the low energyefficient form of carbon. Therefore, a considerable amount of energy is needed to turn it into usable reduced products [96]. In this regard, BES could provide a practical approach via a bioprocess described as bio-electrosynthesis, that needs even relatively mild conditions. BEC is a well-established technology that turns carbon dioxide into useful products and biofuels. BEC meets all the criteria of green synthesis techniques. It utilizes microbes since low-cost and sustainable catalysts may work under atmospheric conditions and, therefore, be fed with carbon dioxide for atmospheric remediation [97].

Methane, which is stronger than most other typical organismic chemicals like acetate, butyrate, or ethanol, is electrochemically generated under biologically applicable conditions ( $\mathrm{pH} 7$ and $25^{\circ} \mathrm{C}$ ) (Eq. (3), and is the most thermodynamically effective substance in the reduction of carbon footprint. More detrimental capacity for jobs has, in fact, been used to mitigate overpotential losses and to increase output rates [98]. The job capacity in this analysis is standardized to the typical hydrogen electrode (SHE).

$\mathrm{CO}_{2}+8 \mathrm{H}^{+}+8 \mathrm{e}^{-} \rightarrow \mathrm{CH}_{4}+2 \mathrm{H}_{2} \mathrm{O}$

Acetic acid is alternative essential product of BES by carbon dioxide reduction. It was found in apparatuses with single or combination acetogenic microorganisms. Acetic acid formed much lesser than the $\mathrm{CH}_{4}$ production potential $(-0.240 \mathrm{~V})$ from carbon dioxide. It can be generated electrochemically in biologically relevant conditions at -0.280 Volts (Eq. 4):

$2 \mathrm{HCO}_{3}^{-}+9 \mathrm{H}^{+}+8 \mathrm{e}^{-} \rightarrow \mathrm{CH}_{3} \mathrm{COO}^{-}+4 \mathrm{H}_{2} \mathrm{O}$

In reality, the overpotential loss has been minimized, and the output rate increased by utilizing more pessimistic working potentials. Nevin et al. [99], for the first time, reported that the electrosynthesis capabilities displayed by the acetic acid by the biotransformation of carbon dioxide at $-0.4 \mathrm{~V}$ were demonstrated by six acetogenic microbes Sporomusa ovata, Sporomusa sphaeriodes, Sporomusa silvacetica, Clostridium ljungdahlii and Moorrella thermoacetica [99]. The potential was above the hydrogen development value, with graphite as the cathode, which has been calculated in an earlier study at a value of $-0.6 \mathrm{~V}$ and an overpotential of $0.2 \mathrm{~V}$.

Besides $\mathrm{CH}_{4}$ and acetic acid, other organic compounds are also made from the carbon dioxide biotransformation process in BES. It is thought that acetyl-CoA played a significant role in synthetic pathways. It should be remembered that enhanced proton-coupled reactions complicate the forming of several $\mathrm{C}-\mathrm{C}$ bonds. Furthermore, an equilibrium model has shown that acetic acid development in BES is related stoichiometrically and energetically with the Wood-Jahl pathway's ATP production and why organic synthesis is not favorable. A microbial electrosynthesis-based BES platform is ideal for the production of value-added chemicals and materials from waste and carbon dioxide as a carbon source. 


\section{Limitations of BES for waste valorization}

The BES-mediated energy generation in the form of bioelectricity and biohydrogen from wastewater as potential substrate is a very complex process governed by many factors that include seed culture, $\mathrm{pH}$, temperature, nutrients availability, hydraulic retention time, hydrogen partial pressure, fermentation end-products, polarization Losses, activation Losses, concentration Polarization, ohmic Losses, microbial interaction with the electrode surface, $\mathrm{O}_{2}$ reduction by the cathode, and biomass pretreatment-linked inhibitors. It is the fact that there are very few studies conducted on these parameters and intensive research is needed to address these issues to enhance the overall process efficiency and make BES-mediated waste valorization is an economically viable and practically applicable process.

\section{Future directions}

Bioelectricity and biohydrogen energy are highly advantageous renewable energy sources in the fight against fossil fuel-based energy. It may be possible to achieve a sustainable carbon neutral operation and be the most costeffective using renewable, inexpensive feedstock, such as lignocellulosic agricultural leftovers and/or carbon-rich wastewater. While using the technique to produce hydrogen from wastewater has shown some issues, mainly related to the wastewater composition hindering microbial hydrolysis reactions and accumulation of acid-rich byproducts, this fermentation technique has a disadvantage in that it produces darker than traditional lactic acid- or alcohol-based fermentation. The bioreactor that MEC has developed can process agricultural waste biomass, VFAs, and other non-degradable organic materials, which speeds up the breakdown of that material, increasing the amount of hydrogen produced. Therefore, connecting MEC/MFC with the dark fermentation system can be an extremely promising approach to optimizing the conversion of pretreated lignocellulosic agricultural wastes and by-products into bio-hydrogen. In this system, dark fermentation predominantly transforms substrates into biohydrogen, carbon dioxide, and VFAs, and the electrohydrogenesis process follows this in MEC for increased biohydrogen conversion efficiency.

\section{Conclusion}

BES technology is a group of comparatively emerging innovations that have tremendous opportunities for energy recovery from a wide variety of contaminants. The chemical energy stored in the wastewater can be converted into electrical energy, which is eco-friendly. BES can significantly influence the existing wastewater treatment technology by enhancing energy efficiency and also by making the process economically viable by energy generation with concurrent waste treatment. The organic matter present in the wastewater will convert or biotransform into either biofuels or value-added chemicals. Further, this technology can also address atmospheric pollution by reducing carbon dioxide levels in the atmosphere. Further, possible waste valorization roots of BES have been discussed in the manuscript. Discussed options towards waste valorization, reduce substrate cost and address waste treatment/ disposal-related issues. Also, the functional simplicity of BES may provide more outstanding options for wastewater recovery and also the recovery of valuable products and resources, such as ammonium or phosphorus. This will possibly include a low-cost and eco-friendly approach for reducing carbon dioxide emissions to the atmosphere.

Acknowledgements This work was supported by Korea Environment Industry \& Technology Institute (KEITI) through Project for developing innovative drinking water and wastewater technologies, funded by Korea Ministry of Environment (MOE) (ARQ202001174001).

Author contributions KC: investigation, data curation, methodology, writing — original draft. ANK: methodology, writing - original draft. TR: methodology, writing-original draft. GK: conceptualization, funding acquisition, supervision, writing - review and editing. S-HK: conceptualization, funding acquisition, supervision, writingreview and editing.

Funding Open access funding provided by University Of Stavanger. Funding information that explains whether and by whom the research was supported.

Availability of data and material Not applicable.

Code availability Not applicable.

\section{Declarations}

Conflict of interest All authors declared no conflict of interest including financial, personal and other relationships with other people and other organizations for the submitted work.

Ethics approval Not applicable.

Consent to participate Not applicable.

Consent for publication All the authors mutually agreed to submit the manuscript to SMAB. 
Open Access This article is licensed under a Creative Commons Attribution 4.0 International License, which permits use, sharing, adaptation, distribution and reproduction in any medium or format, as long as you give appropriate credit to the original author(s) and the source, provide a link to the Creative Commons licence, and indicate if changes were made. The images or other third party material in this article are included in the article's Creative Commons licence, unless indicated otherwise in a credit line to the material. If material is not included in the article's Creative Commons licence and your intended use is not permitted by statutory regulation or exceeds the permitted use, you will need to obtain permission directly from the copyright holder. To view a copy of this licence, visit http://creativecommons.org/licenses/by/4.0/.

\section{References}

1. Yadavalli R, Ratnapuram H, Motamarry S, Reddy CN, Ashokkumar V, Kuppam C. Simultaneous production of flavonoids and lipids from Chlorella vulgaris and Chlorella pyrenoidosa. Biomass Convers Biorefinery. 2020. https://doi.org/10.1007/ s13399-020-01044-X.

2. Mohan SV, Chandrasekhar K, Chiranjeevi P, Babu PS (2013) Biohydrogen production from wastewater. In: Chang J-S, Hallenbecka PC, Larroche C (eds) Biohydrogen. Elsevier, Amsterdam, p 223-57. https://doi.org/10.1016/B978-0-444-59555-3.00010-6.

3. Chandrasekhar K, Cayetano RDA, Mehrez I, Kumar G, Kim $\mathrm{S}-\mathrm{H}$. Evaluation of the biochemical methane potential of different sorts of Algerian date biomass. Environ Technol Innov. 2020;20: 101180. https://doi.org/10.1016/j.eti.2020.101180.

4. Yadavalli R, Ratnapuram H, Peasari JR, Reddy CN, Ashokkumar V, Kuppam C. Simultaneous production of astaxanthin and lipids from Chlorella sorokiniana in the presence of reactive oxygen species: a biorefinery approach. Biomass Convers Biorefinery. 2021;2021:1-9. https://doi.org/10.1007/s13399-021-01276-5.

5. Sivagurunathan P, Kuppam C, Mudhoo A, Saratale GD, Kadier A, Zhen G, et al. A comprehensive review on two-stage integrative schemes for the valorization of dark fermentative effluents. Crit Rev Biotechnol. 2018;38:868-82. https://doi.org/10.1080/07388 551.2017.1416578.

6. Singh M, Chavali M, Enamala MK, Obulisamy PK, Dixit R, Kuppam C (2020) Algal bioeconomy: a platform for clean energy and fuel. In: Biorefineries: a step towards renewable and clean energy, clean energy production technologies. Springer, Berlin. https:// doi.org/10.1007/978-981-15-9593-6_13

7. Patel V, Pandit S, Chandrasekhar K. Basics of methanogenesis in anaerobic digester. Microb Appl. 2017;2:291-314. https://doi.org/ 10.1007/978-3-319-52669-0_16.

8. Mohan SV, Devi MP, Reddy MV, Chandrasekhar K. Bioremediation of petroleum sludge under anaerobic microenvironment: influence of biostimulation and bioaugmentation. Environ Eng Manag J. 2011;10:1609-16.

9. Enamala MK, Enamala S, Chavali M, Donepudi J, Yadavalli R, Kolapalli B, et al. Production of biofuels from microalgae-a review on cultivation, harvesting, lipid extraction, and numerous applications of microalgae. Renew Sustain Energy Rev. 2018;94:49-68. https://doi.org/10.1016/j.rser.2018.05.012.

10. Park J-HJ-HH, Chandrasekhar K, Jeon BHB-HB-HH, Jang M, Liu Y, Kim S-HHS-H. State-of-the-art technologies for continuous high-rate biohydrogen production. Bioresour Technol. 2021;320:124304. https://doi.org/10.1016/j.biortech.2020. 124304 .
11. Meena RAA, Yukesh Kannah R, Sindhu J, Ragavi J, Kumar G, Gunasekaran $\mathrm{M}$, et al. Trends and resource recovery in biological wastewater treatment system. Bioresour Technol Rep. 2019;7: 100235. https://doi.org/10.1016/j.biteb.2019.100235.

12. Kumar AN, Yoon J-J, Kumar G, Kim S-H. Biotechnological valorization of algal biomass: an overview. Syst Microbiol Biomanufact. 2020;2020:1-11. https://doi.org/10.1007/ s43393-020-00012-w.

13. Venkata Mohan S, Chiranjeevi P, Chandrasekhar K, Babu PS, Sarkar O (2019) Acidogenic biohydrogen production from wastewater. In: Pandey A, Mohan SV, Chang J-S, Hallenbeck PC, Larroche C (eds) Biohydrogen. Elsevier, Amsterdam, p 279-320. https://doi.org/10.1016/b978-0-444-64203-5.00011-3.

14. Flagiello F, Gambino E, Nastro RA, Kuppam C. Harvesting energy using compost as a source of carbon and electrogenic bacteria. Bioelectrochemical Syst. 2020. https://doi.org/10.1007/ 978-981-15-6868-8_9.

15. Liu H. Microbial fuel cell: novel anaerobic biotechnology for energy generation from wastewater. Anaerob Biotechnol Bioenergy Prod Princ Appl. 2009. https://doi.org/10.1002/9780813804 545.ch10.

16. Florio C, Nastro RA, Flagiello F, Minutillo M, Pirozzi D, Pasquale $\mathrm{V}$, et al. Biohydrogen production from solid phase-microbial fuel cell spent substrate: a preliminary study. J Clean Prod. 2019;227:506-11. https://doi.org/10.1016/j.jclepro.2019.03.316.

17. Mohan SV, Chandrasekhar K. Solid phase microbial fuel cell (SMFC) for harnessing bioelectricity from composite food waste fermentation: influence of electrode assembly and buffering capacity. Bioresour Technol. 2011;102:7077-85. https://doi.org/ 10.1016/j.biortech.2011.04.039.

18. Kumar AK, Reddy MV, Chandrasekhar K, Srikanth S, Mohan SV, Kiran Kumar A, et al. Endocrine disruptive estrogens role in electron transfer: bio-electrochemical remediation with microbial mediated electrogenesis. Bioresour Technol. 2012;104:547-56. https://doi.org/10.1016/j.biortech.2011.10.037.

19. Lenin Babu M, Venkata Subhash G, Sarma PN, Venkata Mohan S, Babu ML, Subhash GV, et al. Bio-electrolytic conversion of acidogenic effluents to biohydrogen: an integration strategy for higher substrate conversion and product recovery. Bioresour Technol. 2013;133:322-31. https://doi.org/10.1016/j.biortech.2013.01.029.

20. Pant D, Singh A, Van Bogaert G, Irving Olsen S, Singh Nigam P, Diels L, et al. Bioelectrochemical systems (BES) for sustainable energy production and product recovery from organic wastes and industrial wastewaters. RSC Adv. 2012;2:1248-63. https://doi.org/ 10.1039/C1RA00839K.

21. Chandrasekhar K, Kadier A, Kumar G, Nastro RA, Jeevitha V (2017) Challenges in microbial fuel cell and future scope. In: Das D (ed) Microbial fuel cell. A bioelectrochemical system that converts waste to watts. Springer, Champaign, p 483-499. https://doi. org/10.1007/978-3-319-66793-5_25.

22. Nastro RA, Gambino E, Toscanesi M, Arienzo M, Ferrara L, Trifuoggi M. Microbial Fuel Cells (MFCs) remediation activity of marine sediments sampled at a dismissed industrial site: what opportunities? J Clean Prod. 2019;235:1559-66. https://doi.org/ 10.1016/j.jclepro.2019.07.019.

23. Modestra JA, Chiranjeevi P, Mohan SV. Cathodic material effect on electron acceptance towards bioelectricity generation and wastewater treatment. Renew Energy. 2016;98:178-87. https:// doi.org/10.1016/j.renene.2016.03.066.

24. Venkata Mohan S, Velvizhi G, Annie Modestra J, Srikanth S. Microbial fuel cell: critical factors regulating bio-catalyzed electrochemical process and recent advancements. Renew Sustain Energy Rev. 2014;40:779-97. https://doi.org/10.1016/j.rser.2014. 07.109. 
25. Venkata Mohan S, Velvizhi G, Vamshi Krishna K, Lenin BM. Microbial catalyzed electrochemical systems: a bio-factory with multi-facet applications. Bioresour Technol. 2014;165:355-64. https://doi.org/10.1016/j.biortech.2014.03.048.

26. Velvizhi G, Venkata Mohan S. Biocatalyst behavior under selfinduced electrogenic microenvironment in comparison with anaerobic treatment: evaluation with pharmaceutical wastewater for multi-pollutant removal. Bioresour Technol. 2011;102:107841093. https://doi.org/10.1016/j.biortech.2011.08.061.

27. Chandrasekhar K (2019) Effective and nonprecious cathode catalysts for oxygen reduction reaction in microbial fuel cells. In: Mohan SV, Varjani S, Pandey A (eds) Microbial electrochemical technology. Elsevier, Amsterdam, p 485-501. https://doi.org/10. 1016/B978-0-444-64052-9.00019-4.

28. Mohan SV, Raghavulu SV, Peri D, Sarma PN. Integrated function of microbial fuel cell (MFC) as bio-electrochemical treatment system associated with bioelectricity generation under higher substrate load. Biosens Bioelectron. 2009;24:2021-7. https://doi.org/ 10.1016/j.bios.2008.10.011.

29. Deval AS, Parikh HA, Kadier A, Chandrasekhar K, Bhagwat AM, Dikshit AK. Sequential microbial activities mediated bioelectricity production from distillery wastewater using bio-electrochemical system with simultaneous waste remediation. Int J Hydrogen Energy. 2017;42:1130-41. https://doi.org/10.1016/j.ijhydene. 2016.11.114.

30. Gude VG. Wastewater treatment in microbial fuel cells-an overview. J Clean Prod. 2016;122:287-307. https://doi.org/10.1016/j. jclepro.2016.02.022.

31. Glaven SM. Bioelectrochemical systems and synthetic biology: more power, more products. Microb Biotechnol. 2019;12:819-23. https://doi.org/10.1111/1751-7915.13456.

32. Chandrasekhar K, Kumar S, Lee B-D, Kim S-H. Waste based hydrogen production for circular bioeconomy: current status and future directions. Bioresour Technol. 2020;302: 122920. https:// doi.org/10.1016/j.biortech.2020.122920.

33. Rabaey K, Rodríguez J, Blackall LL, Keller J, Gross P, Batstone $\mathrm{D}$, et al. Microbial ecology meets electrochemistry: electricitydriven and driving communities. ISME J. 2007;1:9-18. https:// doi.org/10.1038/ismej.2007.4.

34. Enamala MK, Dixit R, Tangellapally A, Singh M, Dinakarrao SMP, Chavali M, et al. Photosynthetic microorganisms (Algae) mediated bioelectricity generation in microbial fuel cell: Concise review. Environ Technol Innov. 2020;19: 100959. https://doi.org/ 10.1016/j.eti.2020.100959.

35. Brown RK, Harnisch F, Wirth S, Wahlandt H, Dockhorn T, Dichtl N, et al. Evaluating the effects of scaling up on the performance of bioelectrochemical systems using a technical scale microbial electrolysis cell. Bioresour Technol. 2014;163:20613. https://doi.org/10.1016/j.biortech.2014.04.044.

36. Caizán-Juanarena L, Borsje C, Sleutels T, Yntema D, Santoro C, Ieropoulos I, et al. Combination of bioelectrochemical systems and electrochemical capacitors: principles, analysis and opportunities. Biotechnol Adv. 2020. https://doi.org/10.1016/j. biotechadv.2019.107456.

37. Chandrasekhar K, Kumar G, Venkata Mohan S, Pandey A, Jeon $\mathrm{BH}$, Jang M, et al. Microbial Electro-Remediation (MER) of hazardous waste in aid of sustainable energy generation and resource recovery. Environ Technol Innov. 2020;19: 100997. https://doi.org/10.1016/j.eti.2020.100997.

38. Chandrasekhar K, Velvizhi G, Venkata MS. Bio-electrocatalytic remediation of hydrocarbons contaminated soil with integrated natural attenuation and chemical oxidant. Chemosphere. 2021;280: 130649. https://doi.org/10.1016/j.chemosphere.2021. 130649.

39. Gambino E, Chandrasekhar K, Nastro RA. SMFC as a tool for the removal of hydrocarbons and metals in the marine environment: a concise research update. Environ Sci Pollut Res. 2021. https://doi.org/10.1007/s11356-021-13593-3.

40. Sravan JS, Nancharaiah YV, Lens PNL, Mohan SV. Cathodic selenium recovery in bioelectrochemical system: regulatory influence on anodic electrogenic activity. J Hazard Mater. 2020;399: 122843. https://doi.org/10.1016/j.jhazmat.2020. 122843.

41. Li F, An X, Wu D, Xu J, Chen Y, Li W, et al. Engineering microbial consortia for high-performance cellulosic hydrolyzates-fed microbial fuel cells. Front Microbiol. 2019. https://doi.org/10. 3389/fmicb.2019.00409.

42. Zheng T, Li J, Ji Y, Zhang W, Fang Y, Xin F, et al. Progress and Prospects of bioelectrochemical systems: electron transfer and its applications in the microbial metabolism. Front Bioeng Biotechnol. 2020. https://doi.org/10.3389/fbioe.2020.00010.

43. Wang G, Guo Y, Cai J, Wen H, Mao Z, Zhang H, et al. Electricity production and the analysis of the anode microbial community in a constructed wetland-microbial fuel cell. RSC Adv. 2019. https:// doi.org/10.1039/c8ra10130b.

44. Rose ND, Regan JM. Changes in phosphorylation of adenosine phosphate and redox state of nicotinamide-adenine dinucleotide (phosphate) in Geobacter sulfurreducens in response to electron acceptor and anode potential variation. Bioelectrochemistry. 2015. https://doi.org/10.1016/j.bioelechem.2015.03.003.

45. He L, Du P, Chen Y, Lu H, Cheng X, Chang B, et al. Advances in microbial fuel cells for wastewater treatment. Renew Sustain Energy Rev. 2017;71:388-403. https://doi.org/10.1016/j.rser. 2016.12.069.

46. Pandit S, Chandrasekhar K, Kakarla R, Kadier A, Jeevitha V. Basic principles of microbial fuel cell: technical challenges and economic feasibility. Microb Appl. 2017. https://doi.org/10.1007/ 978-3-319-52666-9_8.

47. Amulya K, Venkateswar Reddy M, Venkata Mohan S. Acidogenic spent wash valorization through polyhydroxyalkanoate (PHA) synthesis coupled with fermentative biohydrogen production. Bioresour Technol. 2014;158:336-42. https://doi.org/10.1016/j. biortech.2014.02.026.

48. Venkata Mohan S, Modestra JA, Amulya K, Butti SK, Velvizhi G. A circular bioeconomy with biobased products from $\mathrm{CO} 2$ sequestration. Trends Biotechnol. 2016;34:506-19. https://doi.org/10. 1016/j.tibtech.2016.02.012.

49. Amulya K, Jukuri S, Venkata MS. Sustainable multistage process for enhanced productivity of bioplastics from waste remediation through aerobic dynamic feeding strategy: process integration for up-scaling. Bioresour Technol. 2015. https://doi.org/10.1016/j. biortech.2015.01.070.

50. Harnisch F, Aulenta F, Schröder U (2011) Microbial fuel cells and bioelectrochemical systems: industrial and environmental biotechnologies based on extracellular electron transfer. In: Comprehensive biotechnology, 2nd edn, vol 6. Elsevier, Amsterdam, $\mathrm{p}$ 643-659. https://doi.org/10.1016/B978-0-08-088504-9.00462-1.

51. Yoruklu HC, Koroglu EO, Demir A, Ozkaya B (2018) The electromotive-induced regulation of anaerobic fermentation: electrofermentation. In: Microbial electrochemical technology: sustainable platform for fuels, chemicals and remediation. Elsevier, Amsterdam, p 739-756. https://doi.org/10.1016/B978-0-444-64052-9. 00030-3.

52. Sravan JS, Butti SK, Sarkar O, Mohan SV (2018) Electrofermentation: chemicals and fuels. In: Microbial electrochemical technology: sustainable platform for fuels, chemicals and remediation. Elsevier, Amsterdam, p 723-737. https://doi.org/10.1016/B9780-444-64052-9.00029-7.

53. Chandrasekhar K, Venkata MS. Bio-electrochemical remediation of real field petroleum sludge as an electron donor with simultaneous power generation facilitates biotransformation of $\mathrm{PAH}$ : effect 
of substrate concentration. Bioresour Technol. 2012;110:517-25. https://doi.org/10.1016/j.biortech.2012.01.128.

54. Chandrasekhar K, Venkata MS. Bio-electrohydrolysis as a pretreatment strategy to catabolize complex food waste in closed circuitry: function of electron flux to enhance acidogenic biohydrogen production. Int J Hydrogen Energy. 2014;39:11411-22. https://doi.org/10.1016/j.ijhydene.2014.05.035.

55. Chandrasekhar K, Venkata MS. Induced catabolic bio-electrohydrolysis of complex food waste by regulating external resistance for enhancing acidogenic biohydrogen production. Bioresour Technol. 2014;165:372-82. https://doi.org/10.1016/j.biortech. 2014.02.073.

56. Kumar P, Chandrasekhar K, Kumari A, Sathiyamoorthi E, Kim BS. Electro-fermentation in aid of bioenergy and biopolymers. Energies. 2018;11:343. https://doi.org/10.3390/en11020343.

57. Pandit S, Chandrasekhar K, Jadha DA, Ghangrekar MM, Das D. contaminant removal and energy recovery in microbial fuel cells. In: Chang Y-C, editor. Microbial biodegradation of xenobiotic compounds, vol. 1. Boca Raton: CRC Press; 2019. p. 76.

58. Jannelli N, Anna Nastro R, Cigolotti V, Minutillo M, Falcucci G. Low $\mathrm{pH}$, high salinity: too much for microbial fuel cells? Appl Energy. 2017;192:543-50. https://doi.org/10.1016/j.apenergy. 2016.07.079.

59. Yeruva DK, Jukuri S, Velvizhi G, Naresh Kumar A, Swamy YV, Venkata MS. Integrating sequencing batch reactor with bio-electrochemical treatment for augmenting remediation efficiency of complex petrochemical wastewater. Bioresour Technol. 2015;188:33-42. https://doi.org/10.1016/j.biortech.2015.02.014.

60. Rodrigo MA, Cañizares P, Lobato J, Paz R, Sáez C, Linares JJ. Production of electricity from the treatment of urban waste water using a microbial fuel cell. J Power Sources. 2007;169:198-204. https://doi.org/10.1016/j.jpowsour.2007.01.054.

61. Chandrasekhar K, Ahn YH. Effectiveness of piggery waste treatment using microbial fuel cells coupled with elutriated-phased acid fermentation. Bioresour Technol. 2017;244:650-7. https:// doi.org/10.1016/j.biortech.2017.08.021.

62. Carmona-Martínez AA, Trably E, Milferstedt K, Lacroix R, Etcheverry L, Bernet N. Long-term continuous production of $\mathrm{H} 2$ in a microbial electrolysis cell (MEC) treating saline wastewater. Water Res. 2015;81:149-56. https://doi.org/10.1016/j.watres. 2015.05.041.

63. Kadier A, Kalil MS, Chandrasekhar K, Mohanakrishna G, Saratale GD, Saratale RG, et al. Surpassing the current limitations of high purity $\mathrm{H} 2$ production in microbial electrolysis cell (MECs): strategies for inhibiting growth of methanogens. Bioelectrochemistry. 2018;119:211-9. https://doi.org/10.1016/j.bioelechem.2017.09. 014.

64. Monetti J, Ledezma P, Virdis B, Freguia S. Nutrient recovery by bio-electroconcentration is limited by wastewater conductivity. ACS Omega. 2019;4:2152-9. https://doi.org/10.1021/acsomega. 8b02737.

65. Lei Y, Du M, Kuntke P, Saakes M, van der Weijden R, Buisman CJN. Energy efficient phosphorus recovery by microbial electrolysis cell induced calcium phosphate precipitation. ACS Sustain Chem Eng. 2019;7:8860-7. https://doi.org/10.1021/acssuschem eng.9b00867.

66. Negassa LW, Mohiuddin M, Tiruye GA. Treatment of brewery industrial wastewater and generation of sustainable bioelectricity by microbial fuel cell inoculated with locally isolated microorganisms. J Water Process Eng. 2021. https://doi.org/10.1016/j.jwpe. 2021.102018.

67. Cecconet D, Molognoni D, Callegari A, Capodaglio AG. Agrofood industry wastewater treatment with microbial fuel cells: energetic recovery issues. Int J Hydrogen Energy. 2018;43:500-11. https://doi.org/10.1016/j.ijhydene.2017.07.231.
68. Firdous S, Jin W, Shahid N, Bhatti ZA, Iqbal A, Abbasi U, et al. The performance of microbial fuel cells treating vegetable oil industrial wastewater. Environ Technol Innov. 2018;10:143-51. https://doi.org/10.1016/j.eti.2018.02.006.

69. Jamal MT, Pugazhendi A, Jeyakumar RB. Application of halophiles in air cathode MFC for seafood industrial wastewater treatment and energy production under high saline condition. Environ Technol Innov. 2020;20:101119. https://doi.org/10.1016/j.eti. 2020.101119.

70. Puig S, Serra M, Coma M, Cabré M, Dolors Balaguer M, Colprim J. Microbial fuel cell application in landfill leachate treatment. J Hazard Mater. 2011;185:763-7. https://doi.org/10.1016/j.jhazm at.2010.09.086.

71. Ali J, Wang L, Waseem H, Sharif HMA, Djellabi R, Zhang C, et al. Bioelectrochemical recovery of silver from wastewater with sustainable power generation and its reuse for biofouling mitigation. J Clean Prod. 2019;235:1425-37. https://doi.org/10.1016/j. jclepro.2019.07.065.

72. Jamal MT, Pugazhendi A. Treatment of fish market wastewater and energy production using halophiles in air cathode microbial fuel cell. J Environ Manage. 2021. https://doi.org/10.1016/j.jenvm an.2021.112752.

73. Chandrasekhar K, Naresh Kumar A, Kumar G, Kim D-H, Song Y-C, Kim S-H. Electro-fermentation for biofuels and biochemicals production: current status and future directions. Bioresour Technol. 2021. https://doi.org/10.1016/j.biortech.2020.124598.

74. Lewis AJ, Borole AP (2018) Bio-electro-refinery: conversion, sustainability, and policy. In: Microbial electrochemical technology: sustainable platform for fuels, chemicals and remediation, $1 \mathrm{st}$ edn. Elsevier, Amsterdam, p 1059-1085. https://doi.org/10.1016/ B978-0-444-64052-9.00044-3.

75. Cusick RD, Bryan B, Parker DS, Merrill MD, Mehanna M, Kiely PD, et al. Performance of a pilot-scale continuous flow microbial electrolysis cell fed winery wastewater. Appl Microbiol Biotechnol. 2011;89:2053-63. https://doi.org/10.1007/ s00253-011-3130-9.

76. Gil-Carrera L, Escapa A, Carracedo B, Morán A, Gómez X. Performance of a semi-pilot tubular microbial electrolysis cell (MEC) under several hydraulic retention times and applied voltages. Bioresour Technol. 2013;146:63-9. https://doi.org/10.1016/j.biort ech.2013.07.020.

77. Hosseinzadeh A, Zhou JL, Altaee A, Baziar M, Li D. Effective modelling of hydrogen and energy recovery in microbial electrolysis cell by artificial neural network and adaptive network-based fuzzy inference system. Bioresour Technol. 2020. https://doi.org/ 10.1016/j.biortech.2020.123967.

78. Rousseau R, Ketep SF, Etcheverry L, Délia ML, Bergel A. Microbial electrolysis cell (MEC): a step ahead towards hydrogen-evolving cathode operated at high current density. Bioresour Technol Rep. 2020. https://doi.org/10.1016/j.biteb.2020.100399.

79. Zhao N, Liang D, Meng S, Li X. Bibliometric and content analysis on emerging technologies of hydrogen production using microbial electrolysis cells. Int J Hydrogen Energy. 2020. https://doi.org/10. 1016/j.ijhydene.2020.09.104.

80. Baeza JA, Martínez-Miró À, Guerrero J, Ruiz Y, Guisasola A. Bioelectrochemical hydrogen production from urban wastewater on a pilot scale. J Power Sources. 2017;356:500-9. https://doi.org/ 10.1016/j.jpowsour.2017.02.087.

81. Badia-Fabregat M, Rago L, Baeza JA, Guisasola A. Hydrogen production from crude glycerol in an alkaline microbial electrolysis cell. Int J Hydrogen Energy. 2019;44:17204-13. https://doi. org/10.1016/j.ijhydene.2019.03.193.

82. Singh A, Sevda S, Abu Reesh IM, Vanbroekhoven K, Rathore D, Pant D. Biohydrogen production from lignocellulosic biomass: technology and sustainability. Energies. 2015. https://doi.org/10. 3390/en81112357. 
83. Zhen G, Lu X, Kumar G, Bakonyi P, Xu K, Zhao Y. Microbial electrolysis cell platform for simultaneous waste biorefinery and clean electrofuels generation: current situation, challenges and future perspectives. Prog Energy Combust Sci. 2017. https://doi. org/10.1016/j.pecs.2017.07.003.

84. Selembo PA, Perez JM, Lloyd WA, Logan BE. High hydrogen production from glycerol or glucose by electrohydrogenesis using microbial electrolysis cells. Int J Hydrogen Energy. 2009;34:5373-81. https://doi.org/10.1016/j.ijhydene.2009.05.002.

85. Kadier A, Simayi Y, Kalil MS, Abdeshahian P, Hamid AA. A review of the substrates used in microbial electrolysis cells (MECs) for producing sustainable and clean hydrogen gas. Renew Energy. 2014;71:466-72. https://doi.org/10.1016/j.renene.2014. 05.052 .

86. Amulya K, Kopperi H, Venkata Mohan S. Tunable production of succinic acid at elevated pressures of $\mathrm{CO} 2$ in a high pressure gas fermentation reactor. Bioresour Technol. 2020. https://doi.org/10. 1016/j.biortech.2020.123327.

87. Younesi H, Najafpour G, Mohamed AR. Ethanol and acetate production from synthesis gas via fermentation processes using anaerobic bacterium. Clostridium ljungdahlii Biochem Eng J. 2005;27:110-9. https://doi.org/10.1016/j.bej.2005.08.015.

88. Griffin DW, Schultz MA. Fuel and chemical products from biomass syngas: a comparison of gas fermentation to thermochemical conversion routes. Environ Prog Sustain Energy. 2012;31:219-24. https://doi.org/10.1002/ep.11613.

89. Friedlingstein P, Andrew RM, Rogelj J, Peters GP, Canadell JG, Knutti R, et al. Persistent growth of $\mathrm{CO} 2$ emissions and implications for reaching climate targets. Nat Geosci. 2014;7:709-15. https://doi.org/10.1038/NGEO2248.

90. Annie Modestra J, Katakojwala R, Venkata MS. CO2 fermentation to short chain fatty acids using selectively enriched chemolithoautotrophic acetogenic bacteria. Chem Eng J. 2020;394: 124759. https://doi.org/10.1016/j.cej.2020.124759.

91. Lan EI, Liao JC. Microbial synthesis of n-butanol, isobutanol, and other higher alcohols from diverse resources. Bioresour Technol. 2013;135:339-49. https://doi.org/10.1016/j.biortech.2012.09.104.
92. Asimakopoulos K, Gavala HN, Skiadas IV. Reactor systems for syngas fermentation processes: a review. Chem Eng J. 2018;348:732-44. https://doi.org/10.1016/j.cej.2018.05.003.

93. Chu N, Liang Q, Jiang Y, Zeng RJ. Microbial electrochemical platform for the production of renewable fuels and chemicals. Biosens Bioelectron. 2020;150: 111922. https://doi.org/10.1016/j. bios.2019.111922.

94. Jiang Y, May HD, Lu L, Liang P, Huang X, Ren ZJ. Carbon dioxide and organic waste valorization by microbial electrosynthesis and electro-fermentation. Water Res. 2019. https://doi.org/10. 1016/j.watres.2018.10.092.

95. del Pilar Anzola Rojas M, Zaiat M, Gonzalez ER, De Wever H, Pant D. Effect of the electric supply interruption on a microbial electrosynthesis system converting inorganic carbon into acetate. Bioresour Technol. 2018. https://doi.org/10.1016/j.biortech.2018. 06.074 .

96. Cuéllar-Franca RM, Azapagic A. Carbon capture, storage and utilisation technologies: a critical analysis and comparison of their life cycle environmental impacts. J CO2 Util. 2015;9:82-102. https://doi.org/10.1016/j.jcou.2014.12.001.

97. Annie Modestra J, Navaneeth B, Venkata Mohan S. Bio-electrocatalytic reduction of $\mathrm{CO} 2$ : enrichment of homoacetogens and $\mathrm{pH}$ optimization towards enhancement of carboxylic acids biosynthesis. J CO2 Util. 2015;10:78-87. https://doi.org/10.1016/j. jcou.2015.04.001.

98. Geppert F, Liu D, van Eerten-Jansen M, Weidner E, Buisman C, ter Heijne A. Bioelectrochemical power-to-gas: state of the art and future perspectives. Trends Biotechnol. 2016. https://doi.org/10. 1016/j.tibtech.2016.08.010.

99. Nevin KP, Woodard TL, Franks AE, Summers ZM, Lovley DR. Microbial electrosynthesis: feeding microbes electricity to convert carbon dioxide and water to multicarbon extracellular organic compounds. MBio. 2010. https://doi.org/10.1128/mBio.00103-10. 